\title{
The experience of childbrith in first-time mothers who received narcotic analgesics during the first stage of labour
}

\author{
L Jantjes, \\ Lecturer : Advanced Midwifery and Neonatal Nursing Science, Nelson Mandela Metropolitan University \\ J Strümpher, \\ Professor, Psychiatric Nursing Science, Nelson Mandela Metropolitan University \\ WJ Kotzé, \\ Emeritus Professor, Nelson Mandela Metropolitan University
}

\section{Keywords:}

First-time mothers; narcotic analgesics; first stage of labour; experiences.

\section{Correspondence address:}

Ms Louise Jantjes

Nursign Science Department

PO Box 77000

Nelson Mandela Metropolitan University

Port Elizabeth, 6034

Tel : (041) 504-2674

Fax : (041) 504-2616

E-mail : tillie.jantjes@nmmu.ac.za

\section{Abstract: Curationis 30(2): 82-90}

This research has focused on the birthing experience of first-time mothers who received the narcotic analgesic combination of Pethidine and Hydroxyzine during the first stage of labour. A qualitative research methodology was used to collect data. Unstructured interviews were held with first-time mothers to obtain accounts of their experience of childbirth. These narrations were audio-taped while the participants were still being cared for in the postnatal ward of the hospital where delivery took place. Nine interviews were conducted with first-time mothers who gave birth normally vaginally after a normal pregnancy and who received a narcotic analgesic in the first stage of labour. The transcribed interviews were analyzed using Tesch's method of descriptive analysis (in Creswell, 1994:115).

Four themes with sub-themes emerged from the analysis. The participants reported on the physical experience of labour and described experiencing a lot of pain for which analgesics were given. They also described how these drugs dulled the pain but made them sleepy and unable to cooperate with the midwives. They described their emotional experiences, which included joy and happiness as well as anxiety, anger and despondence. They also reported that they were not sufficiently informed about labour and child-birth. In the last theme they described the methods they used to help them cope with labour including distracting techniques, leaning on a supportive person or praying. Guidelines to help midwives overcome these problems were developed.

\section{Abstrak}

Hierdie navorsing het gefokus op die ervaring van moeders wat vir die eerste keer geboorte geskenk het, en wat tydens die eerste stadium van die baringsproses 'n analgetiese (pynstillende) kombinasie Pethidine en Hydroxydine ontvang het. ' $\mathrm{n}$ Kwalitatiewe navorsingsmetodologie is gebruik om data in te samel. Ongestruktureerde onderhoude is met die moeders gevoer ten einde insig van hulle belewenis van die baringsproses te verkry. Hierdie vertellings is tydens kraamnasorg op band vasgelê, in die hospitaal waar die bevallings plaasgevind het. Nege onderhoude is gevoer met die moeders wat na 'n normale swangerskap op normale wyse vaginaal geboorte geskenk het en wat narkotiese analgetika tydens die eerste stadium van baring ontvang het. Die getranskribeerde onderhoude is geanaliseer aan die hand van Tesch se metode van inhoudsanalise (in Cresswell, 1994:115).

Vier temas met sub-temas is deur die 
analise geïdentifiseer. Die deelnemers het gerapporteer oor die fisieke kraamervaring, en hulle het beskryf hoedat hulle erge pyn ondervind het waarvoor hulle analgetika ontvang het. Hulle het ook beskryf hoedat die pynmiddels die pyn verflou het. Die pynmiddels het die vrouens egter vaak gemaak en het sodoende inbraak gemaak op hulle vermoë om met die vroedvroue saam te werk. Hulle het hulle emosionele belewenisse beskryf, wat vreugde en blydskap, sowel as angs, aggressie en radeloosheid ingesluit het. Hulle het ook vertel dat hulle nie goed genoeg ingelig was omtrent die kraam- en baringsproses nie. In die laaste tema het hulle die metodes wat hulle gebruik het om die kraamproses te hanteer, beskryf. Hierdie hanteringsmetodes sluit in die gebruik van tegnieke om hulle aandag af te lei, deur te steun op ' $n$ ondersteuningspersoon, of om te bid. Riglyne aan vroedvroue om hierdie probleme te oorkom is ontwikkel.

Sleutelwoorde: Eerste-keer moeders; narkotiese analgetikum; eerste stadium van baring; ervarings.

\section{Introduction}

Although painless childbirth is known to occur, most women experience varying degrees of pain when in labour (De Kock \& Van der Walt, 2004:15-1). Pain is said to dominate labour and is considered to be more severe than pain associated with most illnesses and trauma conditions. Women's reactions to pain are as varied as the degrees of pain experienced. Women, in general, are willing to experience some degree of pain in labour but they prefer not to be overwhelmed by it. Women express the need to be in control of their birthing experience. For this reason the type of pain control measure utilized should be effective, serve the purpose of pain control without any undue complications to the fetus and/or the infant and should still allow the woman to be in control.

\section{Problem statement}

During the researcher's contact with labouring women at government hospitals, it became evident that some women who received narcotic analgesics during labour appeared to be unhappy about the manner in which pain was managed during labour. They stated that they felt drowsy and could, therefore, not cooperate well with the nurses. They could also not spend quality time with their newborn babies as they were unable to hold them properly due to drowsiness. They reported that their own descriptions of pain, as well as their own preferences, received little consideration. This led the researcher to question how labouring women experienced labour when they received narcotic analgesics.

\section{Aims of the study}

The aims of the study were to:

Explore and describe the
childbirth experiences of first-
time mothers who received the
narcotic analgesic combination
of Pethidine and Hydroxyzine
during the first stage of labour.
Generate guidelines to assist
midwives in selecting a method
of pain relief for individual
participants.

\section{Paradigmatic perspectives}

The Nursing Accompaniment Theory of Kotzè (Kotzè, 1998) was used as a theoretical framework for this research. Kotzè defines nursing accompaniment as the planned and deliberate intervention by the nurse/midwlfe to enable the patient to overcome his/her need for help and support by accepting responsibility, identifying with the norms of a new lifestyle, regaining self-reliance and the finding and giving of meaning to his/ her life. She further states that accompaniment complements and forms part of responsible management, teaching and clinical functioning in every nursing situation (Kotzè, 1998:19).

Within the context of this research it is clear that nursing accompaniment, in the form of effective perinatal education, guidance and support for the woman during labour and childbirth, plays a vital role in helping her to prepare for, and begin to cope with, the new role of mother awaiting her.

\section{Context of the study}

The study was conducted in the labour ward where participants gave birth to their babies. Participants were allowed to keep upright and mobilize during the first stage of labour, but they could rest on their beds when they felt like it. The presence of a supportive person was encouraged throughout the labour. Narcotic analgesics were given on participants' request and with due observation of hospital policy.

\section{Research design and method}

The study was qualitative, exploratory, descriptive and contextual in nature and was conducted in two phases. Data were collected and analysed during the first phase, producing themes and subthemes. These were used to develop guidelines for practice during the second phase.

\section{Data Collection}

The research population consisted of first-time mothers who gave birth at one of the local hospitals. Purposive sampling was done and the following criteria had to be met for inclusion in the study:

- Participants had to be first-time mothers who received Pethidine and Hydroxyzine during the first stage of labour and subsequently had a normal vaginal delivery.

- $\quad$ The condition of mother and baby had to be satisfactory, bonding must have taken place and the mother had to be wellrested.

- $\quad$ The interview had to be conducted within twelve hours of delivery in the hospital where the delivery took place.

The researcher encountered prospective participants who met the inclusion criteria in the labour ward and invited them to participate in the study. Those who agreed to participate were given an informed consent form to sign in the presence of the researcher and a witness (see data saturation below).

Data were collected using unstructured interviews with one central question, namely: "Please tell me your story of the birth of your baby". The researcher conducted interviews on a one-to-one basis in a quiet, single ward in the hospital where the first-time mothers had given birth to their infants. The researcher ensured that each participant's infant was cared for by a responsible person during interviewing. Interviews were audiotaped and transcribed verbatim. Field notes were made at the end of each interview. Interviews continued until data saturation occurred, as was demonstrated by repeating themes. Saturation of data therefore determined 


\begin{tabular}{|c|c|c|}
\hline STRATEGY & ACTIONS & APPLICATIONCRITERIA \\
\hline \multirow[t]{6}{*}{ Credibility } & $\begin{array}{l}\text { Prolonged and varied field } \\
\text { experience }\end{array}$ & $\begin{array}{l}\text { - Conducting phenomenological interviews until data } \\
\text { were saturated. } \\
\text { - The researcher is a practicing midwife-lecturer. }\end{array}$ \\
\hline & Reflexivity & Taking field notes. \\
\hline & Triangulation & $\begin{array}{l}\text { Conducting unstructured interviews, taking of field } \\
\text { notes and conducting a literature review on women's } \\
\text { experiences of childbirth. to verify themes and sub- } \\
\text { themes. }\end{array}$ \\
\hline & Member checking & $\begin{array}{l}\text { Member checking and peer evaluation through } \\
\text { undertaking a literature control with regard to women's } \\
\text { experience of childbirth. } \\
\text { Use of an independent coder. }\end{array}$ \\
\hline & Authority of the researcher & $\begin{array}{l}\text { Research was supervised by two nurse researchers } \\
\text { holding doctoral degrees in nursing and who are well- } \\
\text { versed in research. } \\
\text { The researcher has: } \\
\text { - } \quad \text { Completed a course in research methodology } \\
\text { at post graduate level. } \\
\text { - } \quad \text { Completed a research treatise successfully. } \\
\text { Attended three workshops on qualitative } \\
\text { research conducted by an internationally } \\
\text { renowned qualitative researcher. }\end{array}$ \\
\hline & Structural coherence & $\begin{array}{l}\text { - The focus was on women's experience of childbirth } \\
\text { after receiving narcotic analgesics. } \\
\text { The results were reflected using Kotzé’s model of } \\
\text { accompaniment (Kotzè, 1998:3-14). }\end{array}$ \\
\hline \multirow[t]{3}{*}{ Transferability } & Nominated sample & Nominated sample. \\
\hline & Dense description & $\begin{array}{l}\text { Complete description of the design and methodology } \\
\text { and accompanying literature control was presented. } \\
\text { All interviews were analyzed to maintain clarity. }\end{array}$ \\
\hline & Guidelines described & $\begin{array}{l}\text { Guidelines formulated in phase } 2 \text { were described } \\
\text { completely. }\end{array}$ \\
\hline \multirow[t]{2}{*}{ Dependability } & Dense description & $\begin{array}{l}\text { Complete description of the research method (see } 2.5 \text { ) } \\
\text { was presented as well as quotes from participants' } \\
\text { comments. }\end{array}$ \\
\hline & $\begin{array}{l}\text { Triangulation } \\
\text { Peer group evaluation }\end{array}$ & $\begin{array}{l}\text { The researcher received expert guidance from a } \\
\text { qualitative nurse researcher. } \\
\text { Data collection through interviewing and field notes. } \\
\text { Literature control was done. } \\
\text { - } \\
\text { Research supervisors had relevant expertise. } \\
\text { An independent coder was used to reach consensus } \\
\text { on identified themes. }\end{array}$ \\
\hline
\end{tabular}




\begin{tabular}{|c|c|c|}
\hline STRATEGY & ACTIONS & APPLICATIONCRITERIA \\
\hline \multirow[t]{4}{*}{ Confirnability } & Confirmability audit & $\begin{array}{l}\text { - The guidelines of phase } 2 \text { were given to one participant } \\
\text { and one practicing midwife to confirm the results. }\end{array}$ \\
\hline & Field notes & Personal logs and field notes were kept. \\
\hline & Triangulation & - $\quad$ Triangulation as described. \\
\hline & Reflexivity & - $\quad$ Reflexivity as described. \\
\hline
\end{tabular}

Adapted utilizing tables from Krefting (1991:214-222).

the sample size Burns \& Grove (2007:348).

\section{Data Analysis}

The transcriptions and field notes formed the data base. The audio taped interviews were transcribed verbatim within 24 hours following each interview. Data were analysed using Tesch's method of descriptive analysis Tesch (in Creswell, 1994:155) where themes and sub-themes were identified by:

- $\quad$ Reading transcriptions and field notes repeatedly to form an overall impression.

- Jotting ideas down in the margins.

- $\quad$ Listing topics.

- Clustering similar topics together and grouping these into major. unique and leftover topics.

- Encoding topics.

- Generating descriptive wording for topics and turning them into categories.

- $\quad$ Reducing topics by.grouping those that were related; this served as a basis for literature control.

- $\quad$ Finalizing abbreviations used for each category.

- Alphabetizing these codes.

- Assembling data according to categories and conducting a preliminary analysis.

- $\quad$ Recoding existing data where necessary.

An independent coder was used to analyze the data and, through consensus discussion, the themes and sub-themes were finalized. Literature control was used to verify these findings. Guba's model of trustworthiness was utilized ensure trustworthiness (Krefting, 1991:212-216). The criteria used for trustworthiness were credibility, transferability, dependability and confirmability (see Table 1).

\section{Ethical aspects}

The researcher ensured a high standard of ethics by adhering to the ethical standards compiled by the South African Society for Nurse Researchers from the planning phase to the reporting phase (SASNR. 1991:74-75; Burns \& Grove, 2007:201). The standards addressed by the researcher included:

- The quality of the researcher:

The researcher has: completed a post-graduate course in research methodology; conducted previous research and attended three workshops on qualitative research. The research was supervised by two nurse researchers with doctoral degrees in nursing.

- Informed consent: Burns and Grove (2007:216) state that it is essential for the researcher to obtain informed consent from the respondents. The researcher achieved this by explaining to the prospective participants: the goal of the study; methodology; steps to ensure anonymity and confidentiality; their right to withdraw from the study at any time. Consent to conduct the research was obtained from the Executive Council for Health of the Department of Health in the Eastern Province, the university research committees as well as the medical superintendent of the hospital where the research was conducted.
Anonymity and confidentiality: Burns and Grove (2007:216) allude to research subjects' right to privacy. The researcher ensured this by not revealing surnames of respondents, conducting interviews privately in a single-bedded hospital ward and wiping clean the cassettes following writing of the research report.

- $\quad$ Freedom from harm: Nursing research should be planned and executed in such a way that the participant is free from any physical or psychological harm (Burns \& Grove, 2007:214). The researcher ensured this by establishing rapport and a trusting relationship with participants; she accomplished this by spending time with them during labour. The researcher ensured that each participant's infant was well cared for during the time of the interview.

\section{Results of the study}

The four themes that were identified are set out in table 2 .

A discussion of these themes with associated sub-themes will now be presented.

\section{Discussion of themes and sub-themes}

Giving birth is largely a physical activity where the woman's body goes through a series of physical, but also emotional and psychological, changes Andrews (in De Kock \& Van der Walt, 2004:2-1). The first theme to be discussed involves physical effects experienced related to labour and childbirth. 
Table 2: Identified themes related to the childbirth experience of first-time mothers who received narcotic analgesics during the first stage of labour

\begin{tabular}{|c|c|c|}
\hline & & THEMES \\
\hline \multicolumn{2}{|c|}{ THEMES } & SUB-THEMES \\
\hline 1) & $\begin{array}{l}\text { Physical effects experienced related to } \\
\text { labour and birth }\end{array}$ & $\begin{array}{l}\text { - } \quad \text { Experiencing pain and the effects of analgesia } \\
\text { - } \quad \text { The medication affected the participant's ability to think } \\
\text { - } \quad \text { No freedom in selecting type of pain medication }\end{array}$ \\
\hline 2) & $\begin{array}{l}\text { Emotional experiences related to labour and } \\
\text { birth }\end{array}$ & $\begin{array}{l}\text { - Negative feelings experienced including despair, frustration, } \\
\text { irritability, fear and anxiety } \\
\text { Positive feelings experienced including relief, satisfaction and } \\
\text { reward } \\
\text { - } \quad \text { Conflicting feclings experienced }\end{array}$ \\
\hline 3) & $\begin{array}{l}\text { Cognitive experiences related to labour and } \\
\text { birth }\end{array}$ & $\begin{array}{ll}- & \text { Insufficient or incorrect information } \\
- & \text { Inability to cooperate } \\
\text { - } & \text { Could not think clearly }\end{array}$ \\
\hline & Coping with labour and birth & $\begin{array}{l}\text { - } \quad \text { Coping strategies used to cope with labour and childbirth } \\
\text { - } \quad \text { Support systems utilized in labour and childbirth }\end{array}$ \\
\hline
\end{tabular}

\section{Theme 1: Physical effects experienced related to}

\section{labour and birth.}

With regard to the physical effects experienced related to labour and childbirth, three sub-themes were identified.

\section{Sub-Theme 1.1: Experiencing pain and the effects of analgesia}

Women worldwide experience a degree of pain associated with labour. Each woman's experience of pain is subjective and unique, ranging widely in intensity from mild to severe Hamilton \& Nolte (in Fraser, Cooper \& Nolte, 2006:454). De Kock and Van der Walt (2004:15-1) state that the pain of labour is different from any other type of pain, as this pain has no associated pathology and the outcome is generally positive. Pain experienced in this study varied from moderate to unbearable pain. One participant who experienced severe pain stated:

“...verskriklike pyn, ... daai pyn kan jy nie beskryf nie....dis oorheersend ....dit was net pyn in jou gedagtes" (... terrible pain ... you cannot describe the pain ... it was overwhelming ... it was only pain on your mind) (Translated)

According to Hamilton \& Nolte Nolte (in Fraser, Cooper \& Nolte, 2006:454 and 456) pain can be expressed in psychic and reflex physical actions sometimes causing increased activity in the sympathetic nervous system. Women occasionally display aggressive and hostile behaviour during labour. In this regard Sherwen, Scoloveno and Weingarten (1995:527) state that threats to self-control or loss of control during labour are associated with a feeling that the uterine contractions are overwhelming.

Although all of the participants received Pethidine and Hydroxyzine for pain during labour some still experienced pain, as is evident in the following quotation: “....daardie inspuiting het niks gedoen nie ... dink daai inspuiting was bedoel om die pyne ... bietjie te stop ... dit het die pyne ... erger gemaak" (that injection did not help at all.... thought that injection was meant to stop the pain ... it made the pain worse) (Translated).

The fact that participants experienced pain after having received pain medication may be ascribed to the timing in administration of analgesics, inadequate or inaccurate information, as well as the specific midwife providing the care to the participant (McCrea, Wright \& MurphyBlack, 1998:177). Hopefully most midwives would fit the category of warm professional carer, rather than the disorganized or cold professional carer described by McCrea et al (1998:177).
Sub-Theme 1.2: The medication affected the participant's ability to think

It appeared that the pain medication affected the participants' thought processes. One participant stated:

"... asof ek in 'n trans is... amper soos $e k .$. in en uit 'consciousness' is "(as if I am in a trance...almost as if I am ... in and out of consciousness) (Translated)

Some women want to be able to account for every experience of their labour and delivery. In this regard Sherwen et al (1995:526) reported that many women have a strong need to experience pain, regardless of the intensity, and they feel a sense of mastery when labour is completed. Sherwen et al (1995:526) emphasize the importance of assessing accurately the woman's expectations of pain, as well as the management of pain.

\section{Sub-Theme 1.3: No freedom in selecting type of pain medication}

Participants explained that their expectations of pain relief were not met due to lack of knowledge regarding the type of pain medication available. One participant said that she was not aware that she was going to have an injection, responding as follows:

"... dokter het net ingestap en ... gesê hulle gaan my ... "n inspuiting gee" (the doctor just walked in and said they are 
going to give me an injection) (Translated)

This participant had planned an unmedicated birth and expressed disappointment and frustration at being given Pethidine. She stated:

" nou weet ek nie hoe dit voel as ek nie die inspuiting het nie. Sô ek moet nou nog "n babakryom te weet" (now I don't know how it feels if I don't have the injection. So I will have to have another baby to know how it feels) (Translated) In a study of primiparous women's knowledge and decision-making for labour, Raynes-Greenow, Roberts, McCaffery and Clarke (2006:1) reported women's need to participate actively in their labour management. Women should be free to discuss, consider and choose how their labour should be undertaken, provided that it is within reason and that unforeseen complications can be dealt with quickly and expertly.

\section{Theme 2: Emotional experiences related to labour and birth}

Cabanac (2002:80) defines an emotion as complex feeling states with psychic, somatic and behavioural responses having particular psychological significance. Positive, negative as well as conflicting emotions related to labour and childbirth was demonstrated.

\section{Sub-Theme 2.1: Negative feelings experienced such as despair, irritability, fear and anxiety}

Negative feelings including despair, irritability, fear and anxiety due to the overwhelming pain, as well as the apparent lack of information, are evident in some of the following responses:

Despair:

“...dit het vir my gevoel ek wil doodgaan...ek wil nie meer aangegaan het nie" (I felt like dying and did not want to continue anymore) (Translated)

Despair relates to a feeling of hopelessness. As is evident from the latter response, participants felt so hopeless at times stating that death would be preferable to continuing with the birthing process. The researcher was unable to access any literature on despair related to the childbirth experience.

Irritability, anger and hostility:

"... as hulle aan my vat, is ek 'irritable'.... wil hulle nie om my' $h$ ? nie" (if they touch me, I am irritable.... did not want them around me.) (Translation)
Irritation is defined as a response aroused due to anger. Anger is said to be a strong feeling of annoyance, displeasure or hostility (MedicineNet.com http:// www.medicinenet.com/script/main/ art.asp? articlekey=37773 02/12/2006).

Hostility refers to a state of unfriendliness and is regarded as a personality trait reflecting a readiness to express anger (http://search.msn.co.za/ rexults.aspx?q=definitiontof +hostility\&mkt=en$\mathrm{ZA} \&$ form $=Q B R E \&$ go. $\mathrm{x}=11$ \&go. $\mathrm{y}=802 /$ 12/2006;

http://www.medicinenet.com/script/ main/art.asp?articlekey=37773 02/12/ 2006). Apparently the participant who expressed irritability did not experience the expected calming effect of Hydroxizine.

Fear and anxiety:

“...bang ... weet nie wat om te verwag nie " (scared ... I did not know what to expect) (Translated)

Live Search (online) describes fear as an unpleasant feeling caused by the presence or anticipation of danger.

( h t t p :// s e a r c h.m s n . co.za/ results.aspx?q=definition+of+fear\&FORM= DNSERR 30/11/2006).

Hamilton and Nolte (Fraser, Cooper \& Nolte, 2006:460) are of the opinion that high levels of anxiety lower women's resistance to pain, causing them to experience pain more intensely. Women may fear that the next contraction may be worse. Unless reassured, they may panic and lose self-control. Anxiety alters perceptions and contributes to fatigue, tension and more intense experience of pain. Lederman (Sherwen et al, 1995:524) demonstrated a relationship between excessive anxiety and secretion of catecholamines. Catecholamines inhibit uterine activity, prolong labour and increase the risk of intrapartum problems. The labouring woman can also experience increased anxiety and/or loss of control when left unattended. In this regard Escott, Slade, Spiby and Fraser (2005:278-291) report that the use of taught coping strategies was associated with lower pain ratings and anxiety in labour. One participant verbalized not wanting to be left alone:

“....ek wil nie meer aangaan met dit nie....want ek was allenig en daar was niemand ... by my' nie... ek het iemand nodig gehad......om net vas te hou" (I did not want to go on anymore as I was alone and there was nobody to support me ... I needed somebody at that time... just to hold onto.) (Translated)
It appears as if the anticipated antianxiety effect of Hydroxozine was ineffective for participants in this study.

\section{Sub-Theme 2.2: Positive feelings experienced such as relief, satisfaction and reward}

Some of the positive experiences observed in this study included feelings of relief, satisfaction and reward. Participants expressed feelings of satisfaction of a task well done and were proud of their accomplishments. Feelings of reward were evident in the following response:

"...toe ek gevoel het die baba kom nou.het ek baie beter gevoel want. ek het gesien my pogings u'as nie hopeloos nie...veral toe ek sien die baba is normaal en hy reageer op my nabyheid..." (when I felt the baby coming it made me feel much better. I saw that my efforts were not fruitless especially when I saw that the baby is normal and that it responded to my presence) (Translated) Relief often accompanies the second stage of labour, as the woman knows that the process of labour will be over soon. The fact that the woman actively participates by pushing to deliver the baby contributes to her feelings of relief (Sherwen et al, 1995:535).

\section{Sub-Theme 2.3: Conflicting feelings experienced}

Participants expressed feeling conflicting emotions of hatred and joy for the baby after delivery.

“... jammer" om dit nou te sê.. ek het baie haat gevoel... want ... soos ek deur die pyn gegaan het ... was ... baie kwaad vir die baba oor die pvne...maar toe die dokter hom oplig! Ek kan dit nie beskryf nie...my hart was so bly!" (I "m sorry to say it, but I felt a lot of hatred because of the pain that I experienced. I was very angry at the baby because of the pain...but when the doctor lifted him up! I can not describe it...my heart was so happy!) (Translated)

The researcher could not find any literature relating to conflicting emotions in labour as expressed in the above response.

\section{Theme 3: Cognitive experiences related to} labour and birth

According to the Live Search (online) the concept cognition refers to the ability to acquire knowledge through reasoning, 
intuition or perception (http:// $\mathrm{s}$ e a r c h.m s n c o. z a / results.aspx? $q=$ definition+of + cognition \&mkt=en-ZA\& form=QBRE\&go. $x=16 \&$ go.y=12 30/11/2006). Cognitive processes are, therefore, related to the ability to think. The cognitive experiences that emerged from this study related to the participants expressing a lack of sufficient or correct information, an inability to cooperate with nursing and medical staff and being unable to think clearly.

\section{Sub-Theme 3.1: Insufficient or incorrect information}

The fact that inadequate or incorrect information was given to the first-time mothers participating was demonstrated in, amongst other things, a lack of understanding about the effect of the pain medication on their bodies or their babies. Patients need information that includes the availability of, and the different types of, pain management strategies available to them (Melender \& Lauri, 1999:178). The following response indicates that the participant was not aware of the fact that the injection would only remove the sharp edge of the labour pain and not relieve it completely.

“...as ek die pyn kry dan dink ek, ek het die inspuiting geky, hoekom is daar pvn?" (...when I get the pain then I think to myself I got the injection, why am I still getting pain?) (Translated)

The researcher could not access any information related to the fact that patients' expectations of pain relief were not met after receiving pain medication.

Responses by some participants also revealed that they had received inadequate information regarding general matters pertaining to labour, for example: "..hy reageer op my nabyheid ... en hy drink so aan my...ek het self gedink hy gaan nie gewoond wees aan my nie..... onmiddellik gedrink" (..he reacts to my presence to be close to me and he drinks on me...I thought that he would not be used to me... drank immediately) (Translated)

The latter quote shows that the participant was unaware that sucking is a reflex that is present in all healthy, term, newborn babies.

\section{Sub-Theme 3.2: Inability to cooperate}

The following response demonstrates the first time mother's inability to cooperate with the staff. “...het ek gedink ek probeer my bes...ek was seker baie swak want die suster het vir my ges?... sodra die kop op kom dan het ek terug gehou" (from my side I thought that I was doing well... was probably very weak because the sister said to me... that as soon as the head came up then I held back) (Translation) This apparent inability of the participant to cooperate with the nurses could be ascribed to the effect of the medication causing sleepiness and possible confusion.

\section{Sub-Theme 3.3: Could not think clearly}

One participant, who wanted to memorize her birthing experience, demonstrated an inability to think clearly:

“...I felt as if I smoked dagga (marijuana)... as if I did not want to be there and yet I promised myself that I am going to experience everything up to the end...I'm going to memorize it"

Some of the unwanted side effects of Pethidine include dizziness and confusion as it is a central nervous system depressant Hamilton \& Nolte (in Fraser, Cooper \& Nolte, 2006456 ).

\section{Theme 4: Coping with labour and birth}

Coping is defined as the process of managing taxing circumstances (The Free Dictionary http://encyclopedia.thefree dictionary.com/Coping+(psychology) 30/11/2006). Two components identified in coping are cognitive and noncognitive processes. The cognitive components include the processes of thought and learning necessary to identify the source of the stress, while the non-cognitive components are automatic and are focussed on stress relief.

\section{Sub-Theme 4.1: Coping strategies used to cope with labour and childbirth}

Participants in this study described the methods that they utilized to cope with the stress they were experiencing.

Belief in God and His presence: One participant expressed a belief in God and His presence and verbalized that she had to thank the Lord for helping her through the process of labour:

“...moet sê dankie vir die Here..." (must say thank you to the Lord...) (Translated) This coping mechanism is referred to as meditation (Thesaurus http:// .selknowledge.com/58666.htm 22/11/ 2006). According to Sherwen et al (1995:859), the spiritual dimension of health care can help participants find comfort, strength and perseverance to cope with crises. These authors contend that participants do have to consider themselves to be religious to benefit from spiritual assistance during labour. Some women may use previous experiences of coping with pain.

\section{Distraction measures}

Distraction entails occupying the brain cells responsible for registering pain impulses with something else. Distraction measures were utilized by some participants in this study. Illustrating the use of distraction, one participant stated:

“...ek het..gedink aan rolprente... as die mense sê 'push' en asem in en uit.daar. was nie tyd om rêrig te dink aan my pyne nie....my' 'mind' het totally op iets anders gedwaal"

(I... thought of films ... when the people say push and breath in and out...there was not really any time to think of my pains...my mind wandered on something totally different) (Translated)

Distraction measures are documented as an effective method of pain relief in labour McCormick \& Nolte (in Fraser, Cooper \& Nolte, 2006: 460). Women in labour may make use of visualisation by picturing more pleasurable memories to distract their attention from the pain that they are experiencing.

\section{Sub-Theme 4.2: Support systems utilized in labour and childbirth}

Another stress management technique utilized by the participants in this study, namely the presence of a supportive person, helped them to cope with the pain. Participants mentioned individual support as well as group support with reference to health care providers as well as significant other persons. One participant shared:

“...geen traan het eers gerol nie...dit het eers gerol toe my ma sê hulle gaan nou ...huistoe...om die waarheid te sê ek het dit (die pyne) goed hanteer...met $X$ (boyfriend) se bystand..." (no tear rolled...it only rolled when my mother said they are going home now...to be truthful I handled it (my pains) well... with X's (boyfriend's) support) (Translated) According to McCormick and Nolte (in Fraser, Cooper \& Nolte, 2006:435), admission to hospital is always a traumatic experience where the presence 
of a support person can reduce anxiety. Another expressed the need for a support person as follows:

"...ek wou nie meer aangegaan het met dit nie...w want ek was allenig en daar was niemand om my by te staan nie...en ek het iemand nodig gehad op daai oomblik" (I did not want to go on with it anymore...because I was alone and there was nobody to support me...and I needed somebody at that time) (Translated)

The goal of support in labour is to enable the woman to cope more effectively. Women who have support in labour, especially if it is the husband's, experience reduced levels of distress. Coping is also more effective when encouraged by a coach, for example with paced breathing and attention-focusing strategies. Hodnett (2001: Cochrane Review Issue 3) reports various benefits of support in labour, including a reduction in pain and duration of labour. No adverse effects of labour support were found (Hodnett, 2001: Cochrane Review Issue 3). Therefore, the use of psychological strategies for pain management is enhanced. Recognizing the need for psychological support, hospital authorities are increasingly permitting and encouraging the partner of the woman in labour to remain with her. McCormick and Nolte (in Fraser, Cooper \& Nolte, 2006:433) report an increase in the practice of support in labour in recent years.

\section{Discussion}

Pain as a sub-theme of physical experiences came through very strongly in the data analysis, as did the effect of drugs. The latter tended to be experienced negatively because they interfered with thought processes. One category that emerged from the sub-theme relating to conflicting feelings experienced was that of hatred towards the infant because of the pain being experienced. However, these feelings were replaced by those of admiration, joy and achievement after the birth of the baby. There was also strong emphasis on the fact that women in labour need support which can be provided by husbands, mothers, boyfriends or nurses.

\section{Guidelines and \\ recommendations}

Underpinning the guidelines generated for this study are the relevant sections from the Bill of Rights as spelled out in the Constitution of the Republic of South
Africa Act, 1996 (Act 108 of 1996) and the Participants Rights Charter (Department of Health, 1999). The Bill of Rights enshrines the rights of all people in South Africa and it affirms the democratic values of human dignity, equality and freedom (Constitution of the Republic of South Africa Act, 1996 [Act 108 of 1996:5]). The Participants Rights Charter (Department of Health, 1999:1) ensures every person the right to participate in decision making on matters affecting his health. The said charter endorses the notion that health care providers should display a positive disposition, demonstrating courtesy, human dignity, patience, empathy and tolerance.

The first-time mother has the right to be accompanied during the stressful time of labour and birth by a person she cares for, trusts and to whom she looks for emotional support and encouragement and she should be made aware of this (Kotzè, 1998:4). The researcher identifies and agrees with Kotzè (1998:1 1) when she states that a sense of security is a prerequisite for successful nursing accompaniment. The midwife should, therefore, endeavour to establish this sense of security in the labouring woman. This can be done by ensuring a trusting relationship with the latter. The midwife should also ensure that the mother is knowledgeable about the process, including what to expect and what her rights are. The midwife needs to understand the experiences of the firsttime mother with regard to hospitalization and identify her fears and anxieties. The first-time mother needs to have an understanding of the midwife's duties in order to utilize the midwife maximally as a resource person (Kotzè, 1998:11).

Although participant education is an essential part of clinical practice, it has apparently failed as indicated by various participant responses in this study. The following aspects should be emphasized when educating first-time mothers, namely:

They have the right to make choices and informed decisions regarding pain control in labour. Each one should take personal control of her birthing experience, which includes questioning decisions made for them by professionals, participating in discussions regarding planned interventions and also refusing interventions with which they do not concur.

- $\quad$ The physiological changes occurring in their bodies and what they can expect during pregnancy and labour. This includes the recognition that pain is a prominent feature of labour but that it is possible to control pain. They should also be aware of the different stages of labour and when to push.

- $\quad$ The interventions that may be performed and that these may cause discomfort or pain.

- $\quad$ The various pain relieving techniques such as correct breathing techniques for the different stages of labour, hypnosis and imaging.

- The effects of analgesics on their bodies, on their ability to think and cooperate and on the foetus. They should be made aware that they have a choice regarding whether to accept or reject analgesics when these are offered.

- $\quad$ The option of identifying a support person whom they wish to have with them during labour and that this person should be encouraged to attend antenatal education classes with them

\section{Conclusion}

In this research study the childbirth experiences of first-time mothers who received the narcotic analgesic combination of Pethidine and Hydroxozine during the first stage of labour were explored and described. Based on the findings, general guidelines to assist midwives in selecting a method of pain relief for individual patients were developed.

These guidelines were underpinned by relevant sections from the Bill of Rights, as spelled out in the Constitution of the Republic of South Africa Act (Act 108 of 1996) and the Participants Rights Charter (Department of Health, 1999) as well as The Nursing Accompaniment Theory of Kotzè (Kotzè, 1998). If these guidelines are implemented both of the desired outcomes of labour should be achieved, namely a safe and healthy mother and child and a positive and rewarding birthing experience. 


\section{Bibliography}

BURNS, N \& GROVE, SK 2007:

Understanding Nursing Research. 4th

Edition. China: Elsevier.

CABANAC, M 2002: What is emotion? Behavioural Processes. 60(2):69-83

CRESWELL, JW 1994: Research Design, Qualitative and Quantitative Approaches. London: Sage Publications.

DE KOCK, J \& VAN DER WALT, C 2004: Maternal and Newborn Care. Lansdowne: Juta Academic.

DEPARTMENT OF HEALTH 1999:

Participants Right Charter. Pretoria: Department of Health.

ESCOTT, D; SLADE, P; SPIBY, H \& FRASER, RB 2005: Preliminary evaluation of a coping strategy enhancement method of preparation for labour. Midwiferv. 21(3): 278-291.

FRASER,DM;COOPER,MA\&NOLTE, AGW (eds) 2006: Myles Textbook for Midwives. African Edition. China: Elsevier.

FRASER,DM; COOPER,MA \& NOLTE, AGW (eds) 2006: Myles Textbook for Midwives. African Edition. China: Elsevier.

HODNETT, ED 2001: Caregiver support for women during childbirth. In: The Cochrane Library, Issue 3. Update Software. Oxford.

KOTZÉ, WJ 1998: An Anthropological Nursing Science: Nursing Accompaniment Theory. Health SA Gesondheid. 3(2): 3-14.

KREFTING, L 1991: Rigor in Qualitative Research: The Assessment of Trustworthiness. The American Journal of Occupational Therapy. 45(3): 214-222.

LIVE SEARCH: Definition of anger and hostility: (MedicineNet.com http:// www.medicinenet.com/script/main/ art.asp? articlekey=37773 02/12/2006). Hostility refers to a state of unfriendliness and is regarded as a personality trait reflecting a readiness to express anger (http://search.msn.co.za/ results.aspx?qedefinitiontof thostility\&mkt=en$\mathrm{ZA} \&$ form $=\mathrm{QBRE} \&$ go. $\mathrm{x}=11$ \&go. $\mathrm{y}=802 \mathrm{l}$ 12/2006; http://www.medicinenet.com/script/ main/art.asp?articlekey $=37773 \quad 02 / 12 /$ 2006).

LIVE SEARCH: definition of cognition Microsoft internet Explorer provided by NMMU ICT Services http:// search.msn.co.za/results.aspx?q=definition+of +fear\&FORM=DNSERR 2006/ $11 / 30$.

LIVE SEARCH: definition of coping Microsoft internet Explorer provided by NMMU ICT Services http:// search.msn.co.za/results.aspx?q=definition +of + cognition \& m kt=enZA\&form=QBRE\&go. $\mathrm{x}=16 \&$ go. $\mathrm{y}=1230 /$ 11/2006

LIVE SEARCH: definition of fear Microsoft Internet Explorer provided by NMMU ICT Services http:// search.msn.co.za/results.aspx?q=definition +of + fear \& m k t =e n-ZA\& form $=Q B R E \&$ go. $x=13 \&$ go. $y=15$.

MCCREA, BH; WRIGHT, ME \& MURPHY-BLACK, T 1998: Differences to midwives' approaches to pain relief in labour. Midwifery. 14(1): 175-179.

MELENDER, H-L \& LAURI, S 1999: Fears associated with pregnancy and childbirth - experiences of women who have recently given birth. Midwifery. 15(3): 177-182.

NIVEN, CA \& GIJSBERS, K 1996: Coping with labour pain. Journal of Pain and Symptom Management. 11(2): $116-$ 125

RAYNES-GREENOW, CH; ROBERTS, CL; MCCAFFERY K \& CLARKE, J 2006: Knowledge and decision-making for labour analgesia of Australian primiparous women. Midwifery. Elsevier. http://www.sciencedirect.com/ science?_ob=ArticleURL\&_udi=B6WN94 M 4 KR 51 - \&_u s e r = 1378441 \&_coverDate $=10 \% 2 \mathrm{~F} 17 \% 2 \mathrm{~F} 2006 \&$ \&alid $=498680719 \&$ \&doc $=2 \&$ fmt $=$ full $\&$ _orig $=$ search \&_cdi $=6957 \&$ sont $=\mathrm{d} \&$ docanchor $=\&$ view $=$ c\&_acct $=C 000052496 \&$ \&ersion $=1$ \&_urlVersion $=0 \&$ \&userid $=1378441 \& \mathrm{md} 5=$ cdf0dd8e8b16382a68ef396c0ba528fe

REPUBLIC OF SOUTH AFRICA 1996: Constitution of The Republic of South Africa (Act No. 108 of 1996). Pretoria: Government Printer.

SHERWEN, LN; SCOLOVENO, MA \&

90

Curationis June 2007
WEINGARTEN, CT 1995: Nursing Care of the Childbearing Family. Norwalk: Appleton \& Lange.

SOUTH AFRICAN SOCIETY for NURSING RESEARCHERS 1991: Ethical Standards for Nurse Researchers. Pretoria: The South African Nursing Association.

THE FREE DICTIONARY. http:// encyclopedia.thefreedictionary.com/ Coping+(psychology)_30/1 1/2006. Farlex 